\title{
Katarzyna Ostalska
}

University of Łódź

\author{
"Soldier Dolls, Little Adulteresses, \\ Poor Scapegoats, Betraying Sisters \\ and Perfect Meat": The Gender of the \\ Early Phase of the Troubles and the \\ Politics of Punishments against Women \\ in Contemporary Irish Poetry
}

\section{ABSTRACT}

This paper examines the literary representation of the beginnings of the Northern Irish Troubles with regard to a gender variable (women's roles and functions ascribed to them, mostly punitively, by men ), in the selected poems by Heaney, Durcan, Boland, Meehan and Morrissey. The reading of Heaney's "Punishment" will attempt to focus not solely on the poem's repeatedly criticized misogyny but on analyzing it in a broader, historical context of the North's conflict. In Durcan's case, his prominent nationalist descent or his declared contempt for any form of paramilitary terrorism (including the IRA) do not seem to prevent him entirely from immortalizing female victims of the Troubles. Boland's attitude seems the most unequivocal: the clear aversion to the language of death and rendering Irish women's experiences (and children's) in this discourse. The article concludes with analysis of Meehan's "Southern" guilt for the situation of Catholics in the North with the simultaneous critique of perpetrated violence and Morrissey's complicated standpoint: atheist/neutral/Protestant/ communist and her striving for the impossible impartiality in a war-ridden and politically divided country. Trying to avoid systemic victimization of Irish women, the paper intends to analyze the historical and political circumstances which made them more susceptible to various forms of attacks at the beginnings of the Troubles, as reflected in the titular labels.

Keywords: contemporary Irish poetry, gender discourse, the Troubles, Northern Ireland. 
In her book Shattering Silence: Women, Nationalism, and The Political Subjectivity in Northern Ireland (1997), referred to by Princeton University Press as "the first feminist ethnography of the violence in Northern Ireland," Begoña Aretxaga, a Professor of Anthropology at Harvard University, stresses that "[w]omen's experiences of the war have been a widely ignored dimension of the "Troubles" ("Ruffling a Few Patriarchal Hairs”). Consequently, the Northern Irish conflict tends to be portrayed in literature and culture as a predominantly male cause, and violent paramilitary attacks related to it are mostly rendered in the masculine war discourse. In the public eye, Irish women during the Troubles were perceived either as mothers mourning their beloved dead or as accidental female casualties of the male-centred struggle. Referring to the Troubles, Aretxaga clarifies that despite the cliché that all "women were united by a shared mothering nature that was contrary to violence. The reality of women's experiences of political violence is, however, more complex and disturbing than these commonly held stereotypes." Therefore, one can see a need to examine in depth the literary representations of women's experiences during the Troubles, rendered by both male poets and Irish women authors. In doing so, one can probe the intersections of the war discourse, sexualized female images and nationalist, symbol-ridden imagery concerning the North. What is more, as emphasized by Lloyd,

feminist critique ... has to be located not in a generalized criticism of "men of violence," but in the analysis of the totalizing effect of an identity thinking that discretely links terrorism to the state in whose name it is condemned. For what is at stake is not so much the practice of violence-which has long been institutionalized in the bourgeois stateas its anesthetization in the name of a freedom expressed in terms of national or racial integration. (30-31)

Bearing this in mind, the following article commences with Heaney's fourth collection North (1975), published during the most intense phase of the Troubles. As most critics cited here agree, the volume derived from the poet's sense of responsibility and from the tribal need for the collective identity of the Catholic minority. In his lecture titled "Feeling into Words" Heaney himself explains that "to forge a poem is one thing, to forge the uncreated conscience of the race, as Stephen Dedalus put is, is quite another and places daunting pressures and responsibilities on anyone who would risk the name of poet" (282). Historically, Heaney's own political conscience seems to have been forged during the Belfast Riots of August 1969. During the protests, as the historian John Dorney states, the RUC used "armoured cars equipped with machine guns" against Catholic 
civilians and did nothing to prevent Loyalists from burning down the two streets inhabited by Catholic families. According to the same source, during the RUC attack on Catholic Divis Flats, a six-year old boy was shot. In total, the 1969 Belfast Riots' death toll amounts to eight people, while 750 sustained serious injuries (Dorney). As such, one can understand the reason why Heaney acknowledges how formative the August 1969 Belfast events were for him: "From that moment the problems of poetry moved from being simply a matter of achieving the satisfactory verbal icon to being a search for images and symbols adequate for our predicament" (279). The possessive pronoun "our" appropriately emphasizes Heaney's identification and his own emotional involvement in the process of forging the "racial" consciousness of his community. Much in line with the above, Brown argues that

[a]ny poet concerned to accept with full responsibility the weight of the actual in the last two decades in the North of Ireland has perforce had to reckon with the challenge of the monstrous events there which have shaken the province like repeated earthquakes. Many Northern poems written since $1968 \ldots$. have been weighed too by earnest, imaginatively serious attempts to comprehend the crisis there in the light of larger experience, deeper truths, more universal realities than the merely local. (65)

Therefore, in his 1975 volume, Heaney strives to look at the Troubles "in the light of larger experience," in order give the North a sense of communal identification. As Goodby highlights: "The outbreak of the 'Troubles' pushed Heaney to reveal in a less crudely sublimated way the sources of his own nationalist and Catholic inheritance of rupture, loss and violence" ("New Wave" 127). Following this line of thinking, Brown explicates the poet's need for seeking the "tribal," community-binding narratives in the past, claiming that "[i] nterpretative myths were accordingly required, explanatory context urgently needed” (65). ${ }^{1}$ Taking into account the time in which it was composed and its politically relevant subject matter, Heaney's collection North constitutes a meaningful "attempt to define and interpret the present by bringing it into significant relation with the past" (Heaney 282). ${ }^{2}$ Indeed, it is as if Heaney had, as Goodby called it,

1 On the other hand, as Johnston points out in "Violence in Seamus Heaney's Poetry," "[o]ne may derive a mythic notion from North, but the poems are too explanatory, tentative, and dialectical to compose a coherent myth" (118).

2 In the frequently cited, self-explanatory passage, Heaney admits having come across P. V. Glob's study The Bog People "the year the killing started, in 1969"; further, the poet acknowledges that "the unforgettable photographs of 
"exhumed" ("New Wave" 127) the needed Northern Irish "tribal" context from the pre-historic bogland in the North of Europe, seeking "analogues with Viking Ireland and with the cults of death and fertility in iron age Denmark" (Brown 65). ${ }^{3}$ In The Bog People, Heaney located "an archetypal pattern" "more than an archaic barbarous rite," as he put it (Heaney 280). In the ancient Mother Goddess Nerthus who, it was claimed, demanded annual human sacrifices to ensure the land's prosperity, Heaney recognized her modern re-embodiment, Kathleen Ni Houlihan, who sanctified "the tradition of Irish political martyrdom" (280). In doing so, as Johnston argues, "a bardic persona enlarges the Ulster violence to include the state of mind called north, the sinister side of man . . . Current inhumanity is displaced by ancient inhumations" (Irish Poetry after Joyce 145-46). Following this vein, one could argue that it is north rather than the North that constitutes Heaney's main preoccupation in his 1975 collection. Similarly to Salman Rushdie's "Imaginary Homelands," Heaney creates his Northern Ireland from the resources available to him: myths, old and new narratives, ancient rituals, his hopes, dreams, fears and obsessions. ${ }^{4}$

After all, North operates around "an exhumation of that which has been buried; psychic, linguistic and the actual disinterment" (Goodby, "Nerw Wave" 127). In his full-length study Irish Poetry Since 1950: From Stillness into History, Goodby clarifies that the need for a myth "provided, it was felt, access to the atavism fuelling the Troubles, at a level below which mere 'rationalism' could not reach" (216). Similarly, Cairns and Richards indicate "Heaney's excavations into the psychic darkness of self and community... in which the modern desire to engage actively in the historical process is rendered impotent by the very completeness of intellectual understanding" (144). If the path to understanding lies beneath the coherent and structured, then, one faces a clear "calculated schizophrenia" (Johnston, Irish Poetry after Joyce 145)..$^{5}$ Accordingly, critics stress that this split manifests itself

these victims blended in my mind with photographs of atrocities, past ... and present, in the long rites of Irish political and religious struggles" (280).

3 Goodby coins an adequate pun term on Heaney's bogland, prehistoric and farmland themes: "crorpses" (Irish Poetry 151).

4 Referring to the poems created during the initial stage of the Troubles, Heaney admits: "I felt it imperative ... to encompass the perspective of a human reason and ... grant the religious intensity of the violence its deplorable authenticity and complexity" (279). The quoted passage undoubtedly elucidates Heaney's official motivation conveyed to his readers, as it does communicate the poet's authorized position. Nonetheless, it does not give much insight into latent and unconscious compulsions in the poet's mind.

5 With reference to "Punishment," Lloyd adds that "the poem rehearses with striking fidelity the propensity of bourgeois thought to use 'reason' to 
even on the structural level of North's layout: its division into two parts (Johnston, Irish Poetry after Joyce 145).

As analyzed here, "Punishment" represents a canonical example of the poet's attempt to integrate the divided parts of his conscious and subconscious loyalties and identifications. In "Punishment," Heaney clearly enters a very unstable ground of explicatory violence, making brutality against women sound more "domesticated" and, thus, less abhorrent. On a declarative level, Heaney, as one could expect, does not justify punishing women for their assumed social offences or misconduct, yet, in a way, his poem does it for him. It is not, however, merely the type of penalty but the grounds for it that can raise one's objections. The problem remains that all the alleged "crimes" depicted in Heaney's "Punishment" are sexually-related transgressions committed (or claimed to have been committed) solely by women. ${ }^{6}$ Contemporarily, openly articulated accusations concerning "voyeurism, necrophilia, blood-sacrifice and hopeless abjection" (Goodby, Irish Poetry 158) seem to overshadow the illusory gender-neutral "tribal” dimension of Heaney's 1975 volume. The group of people can never become the inclusive community if one fraction of it, is seen as more disadvantaged than others, regardless whether on political or gender grounds. If, as Corcoran claims, the poet performs his "service to community-which is, in Heaney's reading of it here, virtually the creation of a community" (100), he seems to be constructing "his community" on physically and discursively violated female corpses.

Heaney's frequently debated poem "Punishment" examined in this article, seems to conceive of the gender-based origin of violence against women as the community binding force. 'With regard to Northern Ireland, punishment attacks of tarring and feathering were executed on women accused of maintaining sexual relations with British soldiers or the RUC policemen. Tarring and feathering was frequently accompanied by retaliatory hair shaving. Recalling the Biblical roots of having women's hair

represent irrationality as the emotional substratum of identifications, which, given as at once natural and logical, are in fact themselves thoroughly 'irrational'" (33).

6 Due to such a perspective, early feminist critics would point out that "[i]n his bog poems, Heaney sexualizes the religious conceptions of Celtic and north European prehistory” (Coughlan 100). Looking at more recent criticism, one could find more and more voices arguing that an "important weakness of North is its use of gender stereotypes” (Goodby, Irish Poetry 161). Much in line, Goodby argues that "Heaney is a poet who cannot deal with . . . female agency, ... woman defined in biological terms.... [he] subsumes the individual female figure" (Irish Poetry 162).

7 Tarring and feathering, as argued by Ashleigh Wallace, can be traced back to the times of Crusades. Moreover, Jeffries provides the exact date of 1189 when Richard the Lionheart first imposed this castigation for theft. 
punitively shaved off, Antony Beevor locates this practice among Visigoths; in medieval times it was used as punishment for alleged female adultery, and it appeared in the 1920s. During the Second World War, as stated by Beevor, the penalty was applied to German female citizens who had "non-Aryan" lovers and to women from the occupied territories who fraternized with German soldiers. Beevor reports that in France during the World War II the so-called "tondues - the shorn women" were tarred, stripped of their clothes and carried on the vans to show them around as warning to other citizens. As clearly demonstrated, tarring and feathering, and hair shaving, possess a perceptible gendered dimension. Heaney's "Punishment" depicts a wide spectrum of chastisement of women, from making them look unattractive, and public shaming, to murder. Notably, as maintained before, in all cases the rationale for male violence is sexually based. In other words, the women depicted in "Punishment" are found guilty of contravening the established sexual code of a given society, be it ancient or modern. Along with each of these platforms, the female body is regarded as the property of the community in which women live, and, as such, this community may feel entitled to enforce "justice" for the misuse of its commodity.

Referring to Heaney's poetry of the examined period, Corcoran argues: "Scrupulously self-critical, it constantly makes enquiry into its own resources and potential, its affiliations and responsibilities; into, in the end, its own exemplary status" (101). In "Punishment," the modifier "artful" is also selected cautiously and consciously. It makes a witty pun on "artistic," whereas, in fact, it denotes the opposite: sly, deceitful, even devious. Defining himself in such a self-depreciating way, might be regarded as a proof of the speaker's sincerity and the impartiality of his own judgement. Assuming that the male voice in the poem is perfectly aware of his textually dubious stand, and yet seems determined to occupy this position in the discourse, weakens rather than strengthens the persona's credibility. Therefore, rather than accepting Corcoran's argument, ${ }^{8}$ in the light of the textual analysis, one feels inclined to subscribe to Lloyd's claim that in "Punishment" the speaker's declared self-awareness turns out to be a carefully assumed "pose of ethical self-query" (32). ${ }^{9}$

8 Corcoran as if defending Heaney reminds about "the extreme pressure of its historical moment," the poet being "self-dividedly alert to its own potential to give offence; acts of offence, and the recrimination, or indeed revenge, consequent on the giving of offence" (103). The critic sees North as the movement towards "a new kind of exemplariness: more elusive and uncertain, still conscious of political obligation” (Corcoran 104).

9 In "Punishment," it is not only what the male persona perceives but how he looks at the female corpse. Coughlan was one of the first to express objection 
In "Punishment," the speaker's obsession with the scrutinized female corpse seems to be so intense that he claims to co-experience the physical sensations that the murdered woman would have gone through. His textually co-experienced sense perceptions derive from his presumptuous usurpations of the victim's inimitable insight into the act of violence that she was exposed to. In the speaker's view, the frosty wind which makes the victim defenceless and puts her body in discomfort, hardens her nipples, as if in a state of sexual stimulation. In a visually gratifying act, these highly sensitive erotic zones are compared to semi-precious stones. Therefore, Eugene O'Brien's statement that "desire is enunciated as some form of racial revenge which functions as a means of validating the selfhood of the nationalist consciousness" (82) is not far from truth. One can argue that amber in "Punishment" stands for the frozen-in-time qualities that embalm the transcendental "tribal" identity "frozen" and unified inside.

In the image of the chest as the rib-cage, the modifier "frail" echoes the alliterated pair of "ribs" and "rigging." The central " $r$ " returns in "drowned," only to be softened by "body in the bog." The frontal sound pattern around "n" reappears in alliterated " the nape / of her neck," "naked," "nipples," "noose a ring" (A Rage for Order 203-04). Heaney's organization of the poem around what he himself previously defined as English masculine consonants rather than Irish feminine vowels puts the argument into further scrutiny. Consequently, Anglo-Saxon kenning is employed in the compact signifier for the head, "brain-firkin." Further in "Punishment," the speaker discloses deriving his textual pleasure from having access to the hidden anatomical female parts: "brain's exposed / and darkened combs, / your muscles' webbing / and all your numbered bones" (A Rage for Order 204). Moreover, "floating rods and boughs" make the persona seek the comparative ground between the dead woman and "a barked sapling" (A Rage for Order 204). What comes to mind is a scalped human and a seedling without its protective shelter, exposed, and not fully developed, never allowed to mature. Skinning the outer, shielding layer of the seed is one more way of denoting the victim's defencelessness and the abuse done to her. The expression "the memories of love" (A Rage for Order 204) seems to destabilize discursively the declining intensity of the faded sense-perceptions. As if to compensate for the loss of love, the speaker declares his affection for the studied dead woman: "I almost

to Heaney's sexualization and highlights the fetishization of the dead female body (97) and the fact that he "aestheticizes the horror of a murdered corpse and presents it as a natural phenomenon" (104). In line with that, other critics also noticed that in the examined poem, "[v] oyeurism is criticized merely as a pose, never for its function in purveying the intimate knowledge of violence by which it is judged" (Lloyd 32). 
love you" (RAO 204). Nonetheless, the modifier "almost" diminishes the textual power of his pronouncement. What lessens it even more considerably is the contrasting clause beginning with "but" ("but would have cast, I know, / the stones of silence”) (A Rage for Order 204).

What strikes one is the decisiveness with which the persona in "Punishment" pronounces his readiness to abstain from a potential intervention during the girl's murder. Willingly or not, his silent unresponsiveness endorses violence against women in the name of ancestral customs and clannish conventions. ${ }^{10}$ In other words, viewed in this light, the "tribal" bonds in the minority communities can be perceived as being reinforced by the shared acts of violence against women in which "the concept of man as producer and as producer of himself through his products, posits an original identity which precedes difference and conflict and which is to be reproduced in the ultimate unity that aesthetic works both prefigure and prepare" (Lloyd 17).

Consequently, in Heaney's "Punishment," numerous passages and images reinforce the "aesthetic politics" 11 of the war discourse. The phrase "a stubble of back corn" (A Rage for Order 204) refers to the remains of the field, burnt to the ground, possibly after the bomb explosion or the gas attack. The blindfolded face implies a potential method of killing: execution by shooting. Similarly, soiled bandages might connote combat wounds but the colour is also reminiscent of soldiers' darkening of the conspicuous, attention-drawing paler body parts. The bandages' tint redirects one to women's black-smeared heads and faces. The dead girl's tarred face and her shaved head constitute the discursive common ground with the Troubles. Like earlier related historical contexts for tarring women, in the North this form of punishment also had clear gender and sexual grounds. During the punishment attacks in the early Troubles, the assaulted women were referred to as "soldier dolls" ("IRA Shave and Daub Girl, 16"). In her article Wallace describes in detail the punitive procedure and particularizes the several stages involved in it. The punishment attack would begin with a female victim being kidnapped and immobilized by masked men ("IRA Shave and Daub Girl, 16"). The woman's hair was shaved, and, then, she was fastened to a lamppost. Burning tar was emptied upon her face and neck. The final stage was putting feathers upon the tar. Wallace stresses the reasons for such an elaborate practice: making the victim exposed,

10 On the other hand, Corcoran claims that Heaney in "humility and submissiveness to the exemplar" performs "his service to a community" (100).

11 Lloyd explains: "Aesthetic politics in turn represents images of origin and unity to convey an ethical demand for the political coherence which will override whatever differences impede a unification in continuity with original identity” (17). 
literally in the limelight, shamed in her own local district. The additional aspect comes from the fact that, during the chastisement, women's sexual appeal is targeted, and their desirability is supposed to be diminished. The speaker in "Punishment" admits witnessing the acts of violence directed against Irish women during the Troubles, seeing them covered in tar and left mortified. He confesses that:

I who have stood dumb

when your betraying sisters,

cauled in tar,

wept by the railings. (A Rage for Order 204)

Declaring: "I who have stood dumb," the speaker proves that he does not shun taking responsibility for his ethically problematic behaviour. And yet he appears to show no trace of remorse. Ruth McDonald from BBC Radio 4, in her account "Has Northern Ireland Left the Past Behind?", draws upon the testimony of MacDermond, another eye-witness to 1970s IRA punishment attacks at the beginning of the Troubles: "People—while they might not even have supported that - they weren't going to interfere, they would have walked on." As demonstrated by MacDermond, the Irish Catholics in the North did not unanimously approve of the attacks on women on the alleged grounds of their fraternizing with occupant soldiers. Nonetheless, a majority of this population would, as the narrator of the poem, "cast a stone of silence" and turn away their eyes. Such an approach of the Catholic minority of pretending not to notice or not to hear was in line with the IRA official policy expressed in the doctrine "whatever you say, say nothing." The legacy of this policy led to the situation that "even today, those who speak out, face walls of silence" (McDonald). The reason for people's silent condoning of the punishment attacks stems from the fact that among the Catholic minority in the North, the IRA were regarded, at that time, as "the gatekeepers of the community" (McDonald). In denial of any legitimate authority fair to Irish Catholics during the Troubles, the IRA assumed the para law-implementing role in Northern Ireland, even though not all nationalists supported their militant course of action. During the conflict, the British Army frequently abused their power and Catholics "had to endure daily armed police and military men patrolling their streets, searching their houses, offering verbal abuse, harassing, arresting and killing” (Aretxaga). Historically, it needs stressing that the poor, working class, Republican communities did not always treat British soldiers with distrust and animosity. Weinraub reminds us that before the escalation of violence in 1970s, armed forces were perceived by Catholics as their defenders against organized, aggressive Protestant gangs. It was only later that RUC and the military's actions 
enraged the minority by indiscriminately searching Catholic homes, placing large neighborhoods under curfew and virtual martial law to weed out a few gunmen, allowing "provocative" Protestant marches in Catholic ghettos, and implementing the provincial government's policy of interning suspected terrorists without trial. The Catholics also say that the army seized up only Catholics. (Weinraub)

Bearing this in mind, even though the persona in "Punishment" gives testimony to the emotive response that the aforementioned aggressive attacks induced in demeaned women, he is still ready to equate the violation of the community rules with treason. Likewise, the adjective "betraying" passes a moral judgement on Irish women's supposedly unpatriotic behaviour. Wallace argues that "feathers ... would stick to the tar for days, acting as a reminder of their so-called crimes against their community." In line with the above, Wallace remarks that this form of public penalty during the Troubles was directed against "perceived anti-social behaviour, with the aim of humiliating victims in front of their friends and neighbours." As shown, the effectiveness of the punishment attacks operates on social dishonour, since targeted women were stigmatized in public as immoral and disloyal. Judging by their disfigured physical appearance, other citizens could immediately recognize "soldier dolls' sins."

As demonstrated so far, "Punishment" revolves around the doublevoiced discursive palimpsest. On the one hand, the speaker seems to empathize with the female victim's standpoint, but, on the other, he patronizingly addresses the dead woman as "little adulteress" (A Rage for Order 204). The modifier "little" reveals his alleged moral superiority over the murdered girl. It moderates the victim's textual authority, depicting her as a petty delinquent who was disciplined for disobeying the conventions of the moral conduct accepted by her community. Concerned at it may seem at first, the expression "[m]y poor scapegoat" (A Rage for Order 204) is in fact equally condescending: as it implies that the target was naïve enough to be manipulated and taken advantage of as the community's sexual deterrent. Consequently, the appellation "my poor" suggests the speaker's ironic detachment from the victim. What is more, the male voice insists on the phrasing "you were punished" (A Rage for Order 204) which is a crude euphemism in comparison to "they murdered you."

In Of Grammatology, Derrida argues that any kind of naming is an act of violence. ${ }^{12}$ In her reading of Derrida in "The Time of Violence:

12 Derrida writes: "To name, to give names that it will on occasion be forbidden to pronounce, such is the originary violence of language which consists in inscribing within a difference, in classifying, in suspending the vocative absolute. To think the unique within the system, to inscribe it there, such is the gesture 
Deconstruction and Value," Grosz rightly observes that " $[\mathrm{t}]$ he violence of nomination, of language or writing, is an expropriation, covered over and concealed by the violence that names itself as the space of non-violence, the field of the law" (194). Therefore, the law disguised as non-violence normalizes the violence of the inscriptive and regulatory system. For that reason, the actual infringement of the legal regulations is partly the effect of the earlier linguistic appropriation and its later systemic legal concealment. Grosz argues:

Empirical violence, war, participates in both these modes of violence (violence as inscription, violence as the containment of inscription, the containment of violence). Mundane or empirical violence ... "denudes: the latent or submerged violence of the law, whose transgression it affirms, while thus affirming the very force and the necessity of law.... the violence we strive to condemn in its racist, sexist, classist and individualist terms is itself a violent consequence of an entire order whose very foundation is inscriptive, differential and thus violent. It is no longer clear how something like a moral condemnation of violence is possible, or at least how it remains possible without considerable self-irony. (194)

One could argue that, in "Punishment," Heaney himself crosses the aforementioned barrier, arguing, in fact, more forcibly in favour of what might be called "civilized violence" rather than against "civilized outrage." Lloyd notices that "[i]n locating the source of violence beyond even sectarian division, Heaney renders it symbolic of a fundamental identity of the Irish race" (31). In this way, the poet seems to agree that in the name of the "tribal," unified consciousness, the violent suppression of any difference can take place. In this way, identitarian "inscriptive" violence appears to acquire a nearly national trait.

Despite the fact that Loyalists officially condemned punishment attacks as "organized brutality" (McDonald), they also used this kind of retribution themselves. According to The Independent, both sides of the conflict in the North, Republicans and Loyalists alike, were responsible for organized attacks upon women from their own communities ("IRA Shave and Daub Girl, 16"). This brings to light another noteworthy aspect: during the military conflict, women get punished not only by "the enemy" forces, but by their own population. The poem's conclusion brings an unexpected finale: the modifier "civilized" with the positive connotations of culture and enlightenment weakens the weight of "outrage," making it if not less fierce and brutal, then more humanized. The modifier "exact" signifies

of the arche-writing, arche-violence, loss of the proper, of absolute proximity, of self-presence" (112, emphasis original). 
the relevance of the deadly revenge, let alone its correctness. The adjective "tribal" echoes "civilized," in the sense of referring to the whole community. Only "intimate" in the understanding of secretive and innermost, brings the question of retribution back to its sexual origin. It is a reminder that women's "crime" was committed in the realm of privacy and not in the public sphere. Brewster rightly locates in the abjected female bodies, the derivative for the collective consciousness sought by the speaker/poet:

The tanned and tarred bodies provide the ground upon which an agonized poetic self-consciousness is forged (crafted authentically and counterfeited), but the exploitation of the exposed female body remains beyond question, as does the mythic inevitability of such rough but exact justice. The poem finds a conniving closure in the precision of its ambiguity and its displacement of the fear of abjection that underlies both "civilized" and "tribal" responses to the act of punishment. (27, emphasis original)

The speaker in "Punishment" does not want to give unanimous endorsement to violence, implying his unofficial authorization via the comprehension of its motives. ${ }^{13}$ It seems that, according to Heaney, even though society has to publicly condemn any violent transgressions, it is governed by the rules that are not less uncivilized than those forbidden by law. The situation of Catholics in the North during the Troubles, was just one instance of such legal procedures. Coughlan aptly observes:

The publicly expressible "civilized outrage" belongs to a language which the persona of all these poems feels is denied him and his ethnic group; he constructs Northern Irish Catholics as, like Celts to the ancient Romans, a race mysterious, barbarous, inarticulate, lacking in civility. But one might argue, the result of this expressed sense of marginalization by the speaker is to make the girl seem doubly displaced: the object of equivocal compassion by a subject himself forced to be covert, himself the object in turn of others' dominant and therefore oppressive civility. (103, emphasis original)

Even if one agrees that the close-knit communities may have the right to their own "tribal justice," the problem remains as to why this tribal justice has to operate on female bodies. Aretxaga notes that during the Troubles in the North

13 As appropriately stressed by Lloyd, "contempt for 'connivance in civilized outrage' is underexamined. . . the 'artful voyeurism' of the poem is supposedly criticized at the safe stance of the remote and lustful 'civilized observer,' yet is smuggled back in as the unspoken and unacknowledged condition of the 'exactness' of 'tribal, intimate revenge'” (31). 
Women's bodies seem to provide a much more malleable material than men's for the inscription of state or nationalist meanings. Thus, their bodies are transformed not only into allegories (female representations of Ireland have a long tradition) but are also subjected to control as the very terrain in which the war is waged. Women's bodies were, like their houses, searched by male soldiers in hated surveillance operations. Women's bodies were tarred and feathered by zealous nationalists in punishment for loving British soldiers during the early seventies. Women's bodies were assaulted in Armagh prison by armed men in searching for forbidden skirts and berets used as IRA uniforms. It was at this level of the body that women revolted and symbolized a different experience of the war.

During the Troubles, the war discourse would turn women not only into "poor scapegoats" but also into "perfect meat" for the war discourse. The latter denomination was used with regard to Irishwomen by Paul Durcan in "In Memory of Those Murdered in the Dublin Massacre, May 1974." The poem commemorates the victims of the bloodiest massacre during the Troubles, with the biggest death toll, which ironically took place in the South and not in the North. The bombing attacks rendered in "In Memory of Those Murdered in the Dublin Massacre, May 1974" were carried out by the UVF Loyalist paramilitaries. ${ }^{14}$ After the TV documentary Hidden Hand: The Forgotten Massacre (1993), the massacre acquired a nickname: "forgotten" and "unsolved," since the terrorists who caused it were never charged and convicted (Fleming). When analyzing the poem, one has to take into account Durcan's disapproval not just of Loyalist but also of Republican militarism. What is more, Durcan has made a name for himself for "his passionate opposition to the IRA" (Goodby, "New Wave" 125), which taking into account the poet's nationalist ancestries, could be regarded as not so obvious but not uncommon either.

"In Memory of Those Murdered in the Dublin Massacre, May 1974" refers to three car bomb explosions in Dublin (twenty six civilians, an unborn child and a stillborn, were killed immediately or died as a result of the explosion); the fourth bombing took place the same day in Monaghan (seven people were killed on the spot or died because of sustained injuries) (Interim Report 2-4). What distinguishes Dublin terrorist attacks from other bomb explosions during the Troubles is the aforementioned externalization of the warfare onto the South and not just the North, the unprecedented scale of fatalities, and the fact that among the dead, there were several very young children and numerous women. The persona in Durcan's poem appears to be shocked that the military conflict can engage into its discourse

14 UVF claimed responsibility for them, though explosions were allegedly supported by the British intelligence (Pallister). 
even unborn children. Two victims of the Dublin explosions were unborn: a nine-month baby who died with Collette Doherty, the mother carrying the child, and a stillborn girl Martha O'Neill delivered after the terrorist attack (Interim Report 2-3). Ironically, once life may not even begin when one can be affected by the nationalist ideology. The expression "grimeridden sunlight" (Durcan 53) seems to indicate the persona's perception of the armed conflict aimed at civilians as a stain on one's moral consciousness. The statement concerning "the labels / That freedom fighters stick onto the lost destinies of unborn / children" (Durcan 53) appears to indicate that the alliterated appellation "freedom fighters" is used in a contemptuously pejorative rather than a glorifying context. The speaker in "In Memory of Those Murdered in the Dublin Massacre, May 1974” claims:

Such a moment as would provide the heroic freedom fighter

With his perfect meat.

And I think of those heroes-heroes? - and how truly

Obscene is war. (Durcan 53)

According to the background data available in the Interim Report on the Report of the Independent Commission of Inquiry into the Dublin and Monaghan Bombings, half of the victims of the first bombing, all victims of the third bombing, and all but one of the second attack were women (1-3). Therefore, Durcan looks at post-massacre Dublin from the perspective of a day after, and through the angle of ordinary, unsuspecting female citizens: young waitresses and an elderly cleaning lady, working in the city centre. The opening line: "And the waitresses cannot help but be happy and gay" (Durcan 53) seems to echo Wordsworth's "Daffodils" (the poem's proper title is "I wandered lonely as a cloud"): "The poet could not but be gay / In such a jocund company” (219). The natural, spontaneous joy of youthful women "As they swipe at the table-tops with their dishcloths-" (Durcan 53) evokes in the persona a moment of epiphanous revelation. Oblivious to the Troubles, girls remain unaware that they could be consumed at any time by armed fanatics as the "perfect meat" for their "freedom" struggle. The conclusion about the war's obscenity criticizes the textual indecency: using sexualized female bodies as the ammunition for male nationalist rhetoric.

The poem "In Memory of Those Murdered in the Dublin Massacre, May 1974" ends with an image of the old Irish woman who mops the floor in the pub, supposedly, removing the traces of the earlier explosions. As Szymborska writes in "The End and the Beginning," "Someone has to push the rubble / to the side of the road, / so the corpse-filled wagons can pass" (228). As frequently stressed by women critics (including Eavan Boland), 
in most cultures, this person would be a woman: aged, unskilled or foreign. Young waitresses are employed to be visible, because their sexual appeal inspires trade, whereas old women clean at the back, as their fatigued, wrinkled faces need to be hidden from view. Cautious as Durcan is in avoiding the idealization of the nationalist discourse, he, nonetheless, falls into a binary opposition trap: juxtaposing young waitresses (seductresses) and an old cleaning lady (a matron/Mother Ireland). Even though " $[\mathrm{t}]$ he aproned old woman who's been sweeping the floor" (Durcan 53 ) is depicted without any redundant poetic embellishments, once immortalized in the poem, as Boland claims, she is turned into a symbol (Object Lessons 143). Hence in "In Memory of Those Murdered in the Dublin Massacre, May 1974," the cleaning lady loses her individuality, and comes to represent all average, blue-collar, hard-working Irish women whose mundane existence, inconsequential from a historical point of view, can be interrupted any moment by the Grand Narrative of the Troubles. The achieved effect may be ethically principled, but it is also not free from the aforementioned rhetorical hazard. Its vulnerability results, as Boland warns, from the appropriation of material women into nationalist symbols, the simplification of the complexity of their experience for the sake of the ideological discourse, and turning real-life women into "dehumanised ornaments" (Object Lessons 143). The persona in "In Memory of Those Murdered in the Dublin Massacre, May 1974" concludes:

The aproned old woman who's been sweeping the floor

Has mop stuck in bucket, leaning on it;

And she's trembling all over, like a flower in the breeze.

She'd make a mighty fine explosion now, if you were to blow her up;

An explosion of petals, of aeons and the waitresses too, flying

breasts and limbs,

For a free Ireland. (Durcan 53)

As shown in the cited passage, the cleaning woman's shivering body (be it from old age, exhaustion or illness) brings to mind the recent bomb explosion. The persona visualizes the muddle of the disjoined limbs, amalgamated both from youthful, desirable female shapes ("the waitresses too, flying / breasts and limbs") and elderly, shaking hands ("she's trembling all over, like a flower in the breeze"). This blood-soaked "installation" of the disjoined, randomly connected female corporeal parts becomes a sacrificial monument dedicated to "a free Ireland." Sad as it is, Durcan's poetic vision has been much confirmed by the documented narrative of the Dublin massacre. The Interim Report cites the account of the eye witness from The Irish Press, 18 May 1974, who recalls the second bombings: "dazed survivors 
saw the normal home-going rush of people turned a scene of carnage. There were bodies, some limbless, some blasted beyond recognition, some burned lying on the pavements" (2). At this point, Heaney's reference to Kathleen Ni Houlihan emerges again at the surface of the discourse.

For Irish poets, born in the South in general, and in Dublin, in particular (i.e. Durcan, Boland and Meehan), 1974 paramilitary Loyalist bombing attacks have become the tangible and palpable, traumatizing manifestation of the Troubles in their no longer safe locality. Boland, in her poem "Child of Our Time," dedicated to underage victims of 1974, writes in a lyrical manner similar to Auden, "Yesterday I knew no lullaby / But you have taught me overnight" (Collected Poems 30). The persona maintains that her song is derived from the killed boy's "final cry," from whom she has learnt:

[...] from your unreasoned end its reason

Its rhythm from the discord of your murder

Its motive from the fact you cannot listen. (Collected Poems 30)

Because, in the speaker's view, the war discourse is the language of death, in "Child of Our Time" writing comes from the dead and only this way can one learn its idiom. Its discourse remains oblivious, as Yeats would phrase it, to "the living stream" (120). The war speech does not encompass the names of animals, bedtime stories, nursery rhymes or protective folktales that can teach one how to survive. The persona in "Child of Our Time” argues:

We who should have known how to instruct

With rhymes for your waking, rhythms for your sleep,

Names for the animals you took to bed,

Tales to distract, legends to protect

Later an idiom for you to keep

And living, learn, must learn from you dead. (Collected Poems 30)

In "Child of Our Time," the speaker assumes the position of the mother who looks at her son's empty cradle. The persona accepts the collective responsibility for being a part of the system that legitimized the war discourse and, thus, enabled the bombing to take place. Similarly to Durcan, Boland evokes the linguistic emblem of the cracked images and fractured bones, severed limbs of people who died in 1974 terrorist attack. As Boland pronounces in "Time and Violence," referring to women in the nationalist tradition, this wound/scar is what language did to us, pleading: "Write us out of the poem. Make us human" (Collected Poems 208). Even though the speaker in "Child of Our Time" identifies with the victim's 
mother, she is not a victim herself: she has found a voice to articulate her protest and her refusal to endorse the discourse of war. The persona maintains:

To make our broken images, rebuild

Themselves around your limbs, your broken

Image, find for your sake whose life our idle

Talk has cost, a new language. Child

Of our time, our times have robbed your cradle.

Sleep in a world your final sleep has woken. (Collected Poems 30)

Concluding, the female voice in "Child of Our Time" asks "for a new language." And she is not the only person who felt such a need after the 1974 Dublin massacre. The BBC in the report "1974: Bombs Devastate Dublin and Monaghan" quotes the words of the Irish Prime Minister, Liam Cosgrave:

I do not know which evil men did this but everyone who practiced violence or preached violence or condoned violence must bear his share of responsibility. It will bring home to us what the people of Northern Ireland have been suffering for five long years.

As shown in Paula Meehan's poem "Borders," without much firsthand experience of the Troubles until 1974, citizens of the Republic, could enjoy a relatively normal, safe, ordinary life, marked by friendliness and positive emotions, experienced "in the easy / Careless way" (Return 20). Faced with the terror of the Troubles in the North, the female voice seems to be apologetic for her own comfortable and unperturbed "Southern" existence. To put it crudely, the Republic's price for its security and prosperity was accepting the partition of Ireland. One can see that the persona feels guilt-ridden and that the embarrassment referred to in the poem is not the addressee's but her own. The speaker in "Borders" admits:

When you spoke of your embarrassment

At the warmth of the South

I laughed and hugged you in the easy

Careless way of a Free Stater

Suckled on the promise

That at last the war had ended. (Return 20)

The final stanza of "Borders" elaborates on the theme of the South/ North division with a gendered reference to the IRA punishment attacks (see "what state had tarred it"). It seems plausible to assume that what 
was unmarked in the South (like the tar) in the North carried the burden of the aforementioned political connotations. The expression "the wars between men" clearly indicates the poet's detachment from the male war discourse. Her argument seems to be that the Troubles were not women's war, and that Irishwomen were trapped in-between two conflicted militant discourses. Such a view, however, does not seem to do justice to those female Republican fighters who supported and were actively engaged in the conflict. The persona in "Borders" concludes:

The difference in a stretch of road,

The colour of the tar

Told what state had tarred it,

Told us of borders

And the wars between men. (Return 21)

Unlike "Borders," Meehan's "No Go Area" renders an insider's perspective on the Troubles. Historically, as stated in Flakes and Elliot's Northern Ireland: A Political Directory 1968-1993 during the Troubles, until 1972, the titular concept denoted mostly the territory beyond the jurisdiction of the Army and the RUC, barricaded and patrolled by the IRA, or less frequently by the UDA (247). In common understanding, in the North, "no go area" means the space beyond the dividing lines of strictly Loyalist or Republican neighbourhoods. In general, the term refers to any dangerous districts, violence and crime-ridden zones, controlled by illegal organizations such as gangs or paramilitaries ("No go area"). Ever since the Troubles, opposed communities have been separated with walls and dividing street lines. The knowledge of this war geography could save one's life, as going into the disputed ground was regarded as a challenge and a provocation.

Entering "No Go Area,"15 as shown in Meehan's poem, Irish women might be "stripped and searched / for hidden weapons" (The Man 31). During the Troubles, as earlier reminded by Aretxaga, "Women's bodies were, like their houses, searched by male soldiers in hated surveillance operations." Aretxaga explains that women were also searched during their prison visits to their male partners. "No Go Area" demands the authorization of one's language, as the choice of words, accent or even intonation could either provoke violence or secure a safe passage. Linguistic identification, starting from the commonplace case in point of Londonderry vs Derry, for example, was one of the distinctive ways in which both communities would

15 The feminist, symbolic reading of this poem is included in my article "Beyond the Border of Body and Language: Moving on: Shapeshifting of Irish Women's Location in Paula Meehan's Poetry.” 
communicate during the Troubles. Furthermore, Meehan implies in "No Go Area," that during the Troubles, as in any other military conflict, women were regarded as gendered war trophies, and, as shown in "Punishment," their representational and actual existence in the war discourse was sexualized (see the reference to zone five in the poem).

As demonstrated in Sinéad Morrissey's 1996 volume There Was Fire in Vancowver, at "UVF-run rank," during the aforementioned linguistic identification, one's accent or the derivation of one's family name could become a matter of life-or-death importance. UVF denotes the Ulster Volunteer Force that is the militant, paramilitary Loyalist organization (Flakes and Elliot 342-45). Only in 1992, "the UVF was believed to have accounted for at least eleven murders"; among the victims there was also a female student, Sheena Campbell (Flakes and Elliot 344). In Morrissey's poem "Thoughts in a Black Taxi," the petrified ("sweated") father who feared that his insufficiently Protestant surname could put his daughter's safety in jeopardy, pleads: "Never say Morrissey again" (19). Although Morrissey's family background is Protestant, she was raised in an atheist, pro-communist family who tried to remain neutral during the Troubles. This ambitious aspiration seems doomed to failure during any war where one can be either "the enemy" or a "brother-at-arms." Seen in this light, even the apparently innocent question may carry a gun-loaded meaning. The persona in "Thoughts in a Black Taxi" admits:

Four days to go until the twelfth, and the bonfire is fourteen feet high.

..

I want to ask them where they got their ladders from.

One "What are You called?" from them, and it would all go black.

I'd have to run to stay whole. (Morrissey 19)

The speaker in Morrissey's poems refuses to be taken hostage in "the wars between men." The persona's weapon is her ironic distance and seeing the actual gun violence in its textually incongruous and gendered context. ${ }^{16}$ The poem depicts the bonfire in the North celebrating the victory of the supporters of William of Orange (predominantly Protestant) over Jacobites (in majority Irish Catholics) in the Battle of the Boyne 1690. The provocative and turbulent (Flakes and Elliot 256-57) annual Orange Order marches on the 12 July, passing through the Catholic districts, are organized to remind the current minority about their subjugated status. In the confrontational Loyalist festivity, the persona in Morrissey's poem perceives a manifestation of the self-

16 Compare my reading of this poem in Towards Female Empowerment. 
important male paramilitaries who derive their illusory authority from intimidating the unarmed citizens. The patriarchal aspect of the militant men's manifestation is rendered in the way the speaker portrays the men on barricades. The sign "Dump Wood Here" puts the celebratory pomposity into question. Metaphorically, it implies that the fire of the Troubles seems to be burning with the donated wood: without people's support, paramilitaries and terrorists would not have managed to keep the whole population of the North in check for so long. The speaker in "Thoughts in a Black Taxi” comments upon it:

I imagine winding my way through the Dump Wood Here signs

And the fallout of black tyres,

Dismantled shelving and donated sofas

To the bare-chested men swanking about on top.

Fascinated by the organisation. (Morrissey 19)

Since I have devoted an entire chapter of my book (2015) to a detailed analysis of violence (especially with regard to the Troubles) in Morrissey's poetry, this article has only touched upon this issue. As outlined briefly, ${ }^{17}$ the representation of the Troubles in Morrissey's early poems oscillates between the poet's ironic estrangement from war discourse and her refusal to accept violence as her daily reality (i.e. "CDN," "There Was Fire in Vancouver," "Thoughts in a Black Taxi") through remembering the people killed in this war (i.e. "Europa Hotel," "In the Valley of Lazarus," "Ciara," "That Summer"), to end up with her mission to "explain" the rationale of the Troubles to confused foreigners (i.e. "English Lesson").

As argued in this article, the offensive gender labels such as "soldier dolls, little adulteresses, poor scapegoats, betraying sisters and perfect meat" disclose the sexual dimension of the war discourse. During the beginning of the Troubles, Irish women to whom those designations were punitively applied were disciplined on social, personal and national grounds. The paper attempted to examine the cultural and historical context behind referring to Irish women in this derogatory way. The examined poems by Heaney, Durcan, Boland, Meehan and Morrissey took into account a gendered perspective upon the literary representation of Irish women in the early phase of the Troubles. The textual analyses demonstrated that male poets focused on their self-assumed or imposed roles in the communities, and their political loyalties could objectify the female characters depicted in

17 The detailed analysis of these poems is included in my monograph Towards Female Empowerment. 
their works from the examined period. In contrast, Boland, Meehan and Morrissey's heterogeneous viewpoints highlighted a richness in women's standpoints during the Troubles and their shared rejection of the sacrificial endurance of involuntarily chosen "women's labels and roles" in the name of political and/or cultural causes.

\section{Works Cited}

“1974: Bombs Devastate Dublin and Monaghan.” Nerws.bbc.co.uk. BBC 17 May 1974. Web. 10 May 2017.

Aretxaga, Begoña. "Ruffling a Few Patriarchal Hairs: Women’s Experiences of War in Northern Ireland." Cultural Survival Quarterly Magazine (March 1995). Culturalsurvival.org. Web. 20 Mar. 2017.

Beevor, Antony. "An Ugly Carnival.” Theguardian.com. Guardian 5 June 2009. Web.10 May 2017.

Boland, Eavan. Collected Poems. Manchester: Carcanet,1995. Print.

---. Object Lessons: The Life of the Woman and the Poet in Our Time. London: Vintage, 1996. Print.

Brewster, Scott. "Abject State: Waste and Exile of the Body in Northern Irish Poetry." The Body and Desire in Contemporary Irish Poetry. Ed. Irene Nordin Gilsenan. Dublin: Irish Academic, 2006. 21-39. Print.

Brown, Terence. "Out of Ulster 2: Heaney and Montague, Mahon and Longley." Irish Poetry Since Kavanagh. Ed. Theo Dorgan. Dublin: Four Courts, 1996. 60-70. Print.

Cairns, David, and Shaun Richards. Writing Ireland: Colonialism, Nationalism and Culture. Manchester: Manchester UP, 1988. Print.

Corcoran, Neil. Poets of Modern Ireland. Cardiff: U of Wales P, 1999. Print. Coughlan, Patricia. “Bog Queens'; The Representation of Women in the Poetry of John Montague and Seamus Heaney." Gender in Irish Writing. Ed. Tony O’Brien Johnson and David Cairns. Milton Keynes: Open UP, 1991. 88-111. Print.

Derrida, Jacques. Of Grammatology. Trans. Gayatri Chakravorty Spivak. Baltimore: The Johns Hopkins UP, 1997. Print.

Dorney, John. "Belfast Riots-A Short History." Theirishhistory.com. 9 Jan. 2013. Web. 10 May 2017.

Durcan, Paul. The Selected Paul Durcan. Ed. Edna Longley. Saskatoon: Thistledown; Belfast: The Blackstaff, 1985. Print.

Flakes, W. D., and Sydney Elliot, eds. Northern Ireland; A Political Directory 1968-1993. Belfast: The Blackstaff, 1994. Print.

Fleming, Diarmaid. "Dublin-Monaghan: Ireland's Unsolved Bomb Massacre 40 Years on." Bbc.com. 14 May 2014. Web.10 May 2017. 
Goodby, John. 'New Wave 1: 'A Rising Tide,' the Poetry in the 60s.” Irish Poetry Since Kavanagh. Ed. Theo Dorgan. Dublin: Four Courts, 1996. 116-35. Print.

---. Irish Poetry Since 1950: From Stillness into History. Manchester: Manchester UP, 2000. Print.

Grosz, Elizabeth. "The Time of Violence: Deconstruction and Value." Cultural Values 2.2-3 (1998): 190-205. Print.

Heaney, Seamus. "Feeling into Words." The Poet's Work: 29 Poets on the Origins and Practice of their Art. Ed. Reginald Gibbons. Chicago: Chicago UP, 1989. 264-83. Print.

"IRA Shave and Daub Girl, 16." Independent.co.uk. The Independent 28 Feb. 1997. Web. 10 May 2017.

Jeffries, Stuart. "Tarring and Feathering: A Brief History of Brutal Revenge.” Theguardian.com. The Guardian 30 Aug. 2007. Web. 10 May 2017.

Johnston, Dillon. Irish Poetry after Joyce. Syracuse, NY: Syracuse UP, 1997. Print.

---. "Violence in Seamus Heaney's Poetry." The Cambridge Companion To Contemporary Irish Poetry. Ed. Matthew Campbell. Cambridge: Cambridge UP, 2003. 113-32. Print.

Joint Committee on Justice, Equality, Defence and Women's Rights. Interim Report on the Report of the Independent Commission of Inquiry into the Dublin and Monaghan Bombings. Dublinmonaghanbombings.org. December 2003. Web.10 May 2017.

Lloyd, David. Anomalous States: Irish Writing and the Post-Colonial Moment. Dublin: The Lilliput, 1993. Print.

McDonald, Ruth. "Has Northern Ireland Left the Past Behind?" Neres. bbc.co.uk. BBC Radio 427 Nov. 2009. Web. 10 May 2017.

Meehan Paula. The Man Who Was Marked by Winter. Loughcrew, Oldcastle, County Meath: The Gallery, 1994. Print.

---. Return and No Blame. Dublin: Beaver Row, 1984. Print.

Morrissey, Sinéad. There Was Fire in Vancouver. Manchester: Carcanet, 1996. Print.

"No go area." Collinsdictionary.com. Collins Dictionary Online. Web. 10 May 2017.

O'Brien Eugene. "The Body as Ethical Synecdoche in the Writing of Seamus Heaney." The Body and Desire in Contemporary Irish Poetry. Ed. Irene Nordin Gilsenan. Dublin: Irish Academic, 2006. 79-100. Print.

Ormsby, Frank, ed. A Rage for Order: Poetry of the Northern Ireland Troubles. Belfast: The Blackstaff, 1992. Print.

Pallister, David. "Quest for Truth over Dublin Bomb Massacre." Theguardian.com. The Guardian 26 Feb. 2001. Web. 10 May 2017. 
Poloczek, Katarzyna. "Beyond the Border of Body and Language: Moving on: Shapeshifting of Irish Women's Location in Paula Meehan's Poetry." Dissolving the Boundaries. Ed. Dorota Filipczak. Łódź: Łódź UP, 2001. 51-65. Print.

---. Towards Female Empowerment-The New Generation of Irish Women Poets: Vona Groarke, Sinéad Morrissey, Caitriona O'Reilly, and Mary O’Donoghue. Łódź: Wydawnictwo Uniwersytetu Łódzkiego, 2015. Print.

Press.princeton.edu. Begoña Aretxaga, Shattering Silence: Women, Nationalism, and the Political Subjectivity in Northern Ireland. Web. 10 May 2017.

Szymborska, Wisława. Poems New and Collected 1957-1997. Trans. from Polish Stanisław Barańczak and Clare Cavanagh. New York: Mariner, 2000. Print.

Wallace, Ashleigh. "Public Humiliation That Was All Too Familiar in the Troubles.” Belfasttelegraph.co.nk. Belfast Telegraph 28 Aug. 2007. Web. 10 May 2017.

Weinraub, Bernard. "Ulster Women Tar 2 Girls for Dating British Soldiers." Nytimes.com. New York Times 11 Nov. 1971. Web. 10 May 2017.

Wordsworth, William. The Collected Poems of William Wordsworth. Ed. Antonia Till. Ware, Hertfordshire: Wordsworth, 1998. Print.

Yeats, W. B. Selected Poetry. Ed. Timothy Webb. London: Penguin, 1991. Print.

\section{Katarzyna Ostalska (née Poloczek) is employed} as Senior Lecturer at the University of Łódź. In 2015, she published her post-doctoral study Towards Female Empowerment-The New Generation of Irish Women Poets: Vona Groarke, Sinéad Morrissey, Caitriona O'Reilly, and Mary O'Donoghue. She co-edited with Marta Goszczyńska two collections of essays in Irish studies: Changing Ireland: Transformations and Transitions in Irish Literature and Culture (2010) and The Playful Air of Light(ness) in Irish Literature and Culture (2011).

katarzyna.ostalska@uni..lodz.pl 